\title{
FROM FIRA TO INVESTMENT CANADA
}

\author{
E. JAMES ARNETT*
}

This paper analyzes the new Investment Canada Act and compares its structure, approach, review process and definitions with those under the Foreign Investment Review Act.

\section{PURPOSE}

Bill C-15 to enact the Investment Canada Act (the "ICA") was introduced into the Canadian Parliament in December, 1984 and is expected to be passed and proclaimed in force in late June or early July, 1985..$^{1}$ It represents a significant change in Canadian attitudes towards foreign direct investment from those which led to the enactment in late 1973 of the Foreign Investment Review Act (the "FIR Act"). ${ }^{2}$

The FIR Act was a direct result of the so-called "Gray Report" published by the federal government in $1972 .{ }^{3}$ The Gray Report was tabled at a time of growing Canadian economic nationalism which reflected both the growing sense of national identity of that era and concern over several high-profile takeovers. The FIR Act was also a product of a minority government. The Trudeau government had originally tabled a bill to enact a Foreign Takeovers Review $\mathrm{Act}^{4}$ but, at the insistence of the New Democratic Party whose support the government needed, had broadened the legislation to cover the establishment of new businesses as well.

This change in Parliamentary attitudes is, perhaps, best exemplified by reference to the respective legislative statements of Parliamentary intention. Subsection 2(1) of the FIR Act stated:

This Act is enacted by the Parliament of Canada in recognition by Parliament that the extent to which control of Canadian industry, trade and commerce has become acquired by persons other than Canadians and the effect thereof on the ability of Canadians to maintain ef fective control over their economic environment is a matter of national concern, and that it is therefore expedient to establish a means by which measures may be taken under the authority of Parliament to ensure that . . . control of Canadian business enterprises may be acquired by persons other than Canadians, and new businesses may be established in Canada by persons, other than Canadians . . . only if it has been assessed that the acquisition of control of those enterprises or the establishment of those new businesses, as the case may be, by those persons is or is likely to be of significant benefit to Canada ...

By contrast, s. 2 of the ICA states:

Recognizing that increased capital and technology would benefit Canada, the purpose of this Act is to encourage investment in Canada by Canadians and non-Canadians that

- Partner, Stikeman, Elliott of Toronto, Ontario. Special Counsel to the Government of Canada in connection with Bill C-15.

1. Bill C-15, 1st Sess., 33rd Parl., 33 Elizabeth II, 1984. In these footnotes this Bill is referred to as the "ICA". This paper was prepared for delivery at the Canadian Petroleum Law Foundation's annual seminar in Jasper on June 14, 1985. The ICA did not receive Royal Assent until June 20,1985. There were, however, no amendments to the ICA from the time this paper was presented until Royal Assent. The ICA was proclaimed in force June 30, 1985, at which time various regulations and guidelines were also tabled.

2. S.C. 1973-74, c. 46 , as am S.C. 1976-77, c. 52 , s. 128 . In these footnotes this statute is referred to as the "FIR Act".

3. Foreign Direct Investment in Canada (Ottawa, 1972) published by the Government of Canada.

4. Bill C-201, 3rd Sess., 28th Parl., 19-20-21 Elizabeth Il, 1970-71-72. 
contributes to economic growth and employment opportunities and to provide for the review of significant investments in Canada by non-Canadians in order to ensure such benefit to Canada.

In enacting the FIR Act in 1973, Parliament recognized the "national concern" about the extent of control of Canadian industry, trade and commerce by non-Canadians. By contrast, in 1985 Parliament recognized "that increased capital and technology would benefit Canada" and that, accordingly, Parliament wished "to encourage investment in Canada by Canadians and non-Canadians that contributes to economic growth and employment opportunities".

The significantly different concern which prompted the enactment of the ICA and repeal of the FIR Act is of more than historical interest. It can be expected to influence the courts when they are called upon to interpret the ICA. For over a decade, the establishment of new businesses, and takeovers of virtually all existing businesses, has been reviewed by the federal government. Now, Parliament intends that only "significant investments" by non-Canadians need to be reviewed by the federal government. At the same time, it has determined that the federal government should actively encourage foreign direct investment. In fact, the change in objectives was so significant that Parliament decided to repeal and replace the FIR Act rather than simply to amend it.

Three general reasons might be cited for this change in Parliamentary attitudes:

(a) With the deep recession in the Canadian economy in 1981 and 1982, political attention focused on how to stimulate economic growth and create employment. Concern over who owned a business became a comparative luxury in the face of rising bankruptcies and unemployment.

(b) There was continuing criticism from the international investment community. In particular, the U.S. administration complained that the commitments which the Canadian government sought to extract from foreign investors interfered with the normal patterns of international trade. The U.S. finally laid a complaint to the Council of the General Agreement on Tariffs and Trade ("GATT") and in late 1983 GATT confirmed a finding that the Canadian government's solicitation of undertakings to purchase goods of Canadian origin, or goods from Canadian sources, was inconsistent with Article III:IV of the GATT, according to which contracting parties must accord to imported products treatment no less favourable than that accorded to like products of national origin in respect of all internal requirements affecting their purchase. ${ }^{5}$ While the Canadian government found ways to comply with this particular problem, ${ }^{6}$ the FIR Act clearly remained an irritant in Canada's foreign relations.

(c) The election in September 1984 of a Progressive Conservative government under the leadership of Brian Mulroney brought to Ottawa a

5. GATT Panel Report, Canada-Administration of the Foreign Investment Review Act (L/5504).

6. Instead of asking applicants for an undertaking to give preferential treatment to Canadian suppliers, FIRA asked for an undertaking to the effect that applicants "will give suppliers resident in Canada a full and fair opportunity to supply...". 
government which was ideologically in favour of freer trade and closer relations with Canada's allies, particularly the U.S. Indeed, the Progressive Conservatives had campaigned on a dismantling of the FIR Act and its twin pillar of the Liberals' program of economic nationalism, namely, the National Energy Program. This ideology was best reflected in Prime Minister Mulroney's statement to the Economic Club of New York a few days after the tabling of Bill C-15 to the effect that "Canada is open for business again". 7

\section{GENERAL SCOPE}

The FIR Act provided that every foreign investor, who was described as a "non-eligible person", and every group of persons any member of which was a non-eligible person, must file an application with the Canadian government if:

(a) such person or group proposed to acquire control of a Canadian business enterprise except where such person or group carried on a related business, the gross assets of the target business did not exceed $\$ 250,000$ and its gross revenues did not exceed $\$ 3$ million,

(b) such person or group proposed to establish a new business in Canada if, immediately before the time when the new business was proposed to be established, no other business was carried on in Canada by that person or group, or

(c) such person or group proposed to establish a new business in Canada and each other business carried on in Canada by that person or group was a business to which the new business would, if it were established, be unrelated.

Each such application was reviewed or "screened" by the Canadian government on a case-by-case basis to determine whether the proposed investment should be allowed as being of "significant benefit to Canada".

The ICA provides, in effect, that every foreign investor, who is described as a "non-Canadian", must file an application with the Canadian government if:

(a) such person proposes to acquire control of a Canadian business whose assets, in the case of a direct acquisition, are valued at $\$ 5$ million or more or, in the case of an indirect acquisition through a foreign corporation, at $\$ 50$ million or more, or

(b) such person proposes to acquire control of a Canadian business, or to establish a new Canadian business, if, in the opinion of the Canadian Cabinet, it is "related to Canada's cultural heritage or national identity" and its review is "in the public interest".

Each such application is reviewed by the Canadian government on a case-by-case basis, in a manner similar to that found under the FIR Act, to determine whether the proposed investment should be allowed as being of "net benefit to Canada". In addition, the ICA requires that all other acquisitions of control of Canadian businesses (within the ICA's defini-

7. See "Notes for a speech by the Prime Minister to the members of the Economic Club of New York, December 10, 1984". 
[VOL. XXIV, NO. 1

tions) by non-Canadians, and any investments to establish a new Canadian business by non-Canadians, are subject to notification to the Canadian government.

Hence, subject to this obligation to notify, Parliament has dropped from the review process all establishments of new businesses, except those of a cultural heritage or national identity concern which the government feels it would be in the public interest to review. In addition, Parliament has introduced thresholds of economic significance below which review is not required. The government estimates that the total number (as opposed to value) of investments subject to review will be reduced by about ninety per cent. Thus, the phrase "significant investments" in s. 2 of the ICA has, in effect, been legislated to mean those that are either economically or culturally significant.

Finally, the ICA contains a positive dimension which was entirely lacking in the FIR Act. The Minister is directed, among other things, to: ${ }^{8}$

(a) encourage business investment by such means and in such manner as the Minister deems appropriate;

(b) assist Canadian businesses to exploit opportunities for investment and technological advancement;

(c) carry out research and analysis relating to domestic and international investment;

(d) provide investment information services and other investment services to facilitate economic growth in Canada;

(e) assist in the development of industrial and economic policies that affect investment in Canada.

It is expected that a substantial separate division within Investment Canada will be established to assist in this encouragement of investment.

\section{FOREIGN INVESTORS}

\section{A. GENERAL}

The characterization and description of foreign investors whose investments are subject to regulation has been totally changed and significantly eased in the ICA from that used in the FIR Act. In the latter, the term used for a foreign investor was "non-eligible person". The term used in the ICA is "non-Canadian".

There has been a significant drafting change in the ICA which helps to clear up one of the significant difficulties under the FIR Act, namely, its application to investments by partnerships and other unincorporated forms of business organization. Both the definition of "non-eligible person" in the FIR Act and that of "non-Canadian" in the ICA address themselves to foreign individuals and foreign governments. However, for business organizations the two Acts are quite different. The FIR Act included in the definition of a "non-eligible person" a definition, in effect, of a non-eligible corporation but not of other non-eligible business organizations. These were dealt with by having the charging provisions refer to investments by a "group of persons any member of which is a non-eligible person". There was no definition of a "group". By contrast, the ICA refers to investments by "non-Canadians", and, in effect, defines a non-Canadian to include an "entity" that is not Canadian-

8. Supran. 1, s. $5(1)$. 
controlled. An "entity" is defined to mean a "corporation, partnership, trust or joint venture".

\title{
B. INDIVIDUALS
}

Under the ICA, a "non-Canadian" means "an individual, a government or an agency thereof or an entity that is not a Canadian". 9 A Canadian is defined to include: ${ }^{10}$

(a) a Canadian citizen,

(b) a permanent resident within the meaning of the Immigration Act, 1976 who has been ordinarily resident in Canada for not more than one year after the time at which he first became eligible to apply for Canadian citizenship . . .

The significant substantive change from the treatment of individuals under the FIR Act is that Canadian citizens can no longer be characterized as non-Canadian if not ordinarily resident in Canada. By contrast, the Foreign Investment Review Regulations passed under the FIR Act prescribed, in effect, that a Canadian citizen would be a non-eligible person if he had applied for citizenship of a country other than Canada or (subject to certain very restricted exceptions) he had been ordinarily resident outside Canada for five or more consecutive years." This disinheriting of non-resident citizens has been commented upon elsewhere by the author. ${ }^{12}$

\section{GOVERNMENTS}

The ICA and the FIR Act are substantially identical in their treatment of foreign governments as non-Canadians whose investments in Canada may be subject to review or, in the case of the ICA, notification. ${ }^{13}$

\section{CORPORATIONS}

The determination of the foreignness of corporations is very different in the ICA from that in the FIR Act. The FIR Act provided that a noneligible person included: ${ }^{14}$

\begin{abstract}
... a corporation incorporated in Canada or elsewhere that is controlled in any manner that results in control in fact, whether directly through the ownership of shares or indirectly through a trust, a contract, the ownership of shares of any other corporation or otherwise, by a (non-eligible individual) or (non-eligible government or agency thereof) or by a group of persons any member of which is a (non-eligible individual) or (noneligible government or agency thereof)...
\end{abstract}

In this definition, separate juridical personality was totally ignored and the ultimate question was by whom the corporation was controlled in fact. The jurisdiction of incorporation was, subject to the one presumption mentioned below, irrelevant. Similarly, the corporation's residence was irrelevant.
9. Id. s. 3.
10. Id.
11. SOR/83-493, s. 3 .
12. E.J. Arnett, “Which Investors Are 'Foreign'?" (1977) 55 Can. Bar Rev. 231.
13. Paragraph (c) of definition of "Canadian" in ICA, s. 3; paragraph (b) of definition of "non-eligible person" in FIR Act, s-s. 3(1).
14. Paragraph (c) of definition of non-eligible person in FIR Act, s. 3(1). 
The assumption running through the various provisions of the FIR Act was that control in fact of a corporation resided with the power to control its management and that this power resided with its board of directors. Accordingly, the holding of enough voting rights to control the shareholders meeting and, therefore, the election of directors, was prima facie presumed to constitute control.

A series of rebuttable presumptions was used to buttress the concept of control in fact. These were that a corporation was (unless the contrary was established) a non-eligible person if $:^{15}$

(a) shares of the corporation to which were attached twenty-five per cent or more of the voting rights ordinarily exercisable at meetings of shareholders of the corporation, in the case of a corporation the shares of which were publicly traded, were owned by one or more non-eligible individuals, non-eligible governments or by one or more corporations incorporated outside Canada;

(b) shares of the corporation to which were attached forty per cent or more of the voting rights ordinarily exercisable at meetings of shareholders of the corporation, in the case of a corporation the shares of which were not publicly traded, were owned by one or more non-eligible individuals, non-eligible governments or by one or more corporations incorporated outside Canada; or

(c) shares of the corporation to which were attached five per cent or more of the voting rights ordinarily exercisable at meetings of shareholders of the corporation (whether or not such shares were publicly traded) were owned by any one non-eligible individual, non-eligible government or corporation incorporated outside of Canada.

While jurisdiction of incorporation of a corporate shareholder was relevant for such presumptions, nevertheless, ultimate control in fact remained the determining factor. The corporation's residence was totally irrelevant.

By contrast, the ICA defines a non-Canadian to include "an entity that is not a Canadian" and defines a "Canadian" to include "an entity that is Canadian-controlled". ${ }^{16}$ It sets forth a series of rules for determining Canadian control of an entity and treats a corporation as a species of entity. The investor, or his lawyer, must proceed through these rules rather like water falling through a series of "catch-basins" until it finds its own level. In addition, there is a special rule in s-s. 26(3) of the ICA whereby a corporation whose shares are publicly traded, and which meets certain tests, is deemed to be a "Canadian" even though it is not a Canadiancontrolled entity.

Subsection $26(1)$ of the ICA is largely self-explanatory and provides as follows:

For the purposes of this Act:

(a) where one Canadian or two or more members of a voting group who are Canadians own a majority of the voting interests of an entity, it is a Canadian-controlled entity;

(b) where paragraph (a) does not apply and one non-Canadian or two or more members of a voting group who are non-Canadians own a majority of the voting interests of an entity, it is not a Canadian-controlled entity;

15. Supran. 2, s. 3(2).

16. Supran. 1, s. 3. 
(c) where paragraphs (a) and (b) do not apply and a majority of the voting interests of an entity are owned by Canadians and it can be established that the entity is not controlled in fact through the ownership of its voting interests by one non-Canadian or by a voting group in which a member or members who are non-Canadians own one-half or more of those voting interests of the entity owned by the voting group, it is a Canadiancontrolled entity; and

(d) where paragraphs (a) to (c) do not apply and less than a majority of the voting interests of an entity are owned by Canadians, it is presumed not to be a Canadiancontrolled entity unless the contrary can be established by showing that

(i) the entity is controlled in fact through the ownership of its voting interests by one Canadian or by a voting group in which a member or members who are Canadians own a majority of those voting interests of the entity owned by the voting group, or

(ii) in the case of an entity that is a corporation or limited partnership, the entity is not controlled in fact through the ownership of its voting interests and two-thirds of the members of its board of directors or, in the case of a limited partnership, two-thirds of its general partners, are Canadians.

When proceeding through the above "catch-basins", it is important to remember that "Canadian" should be read to mean a Canadian citizen, a permanent resident, a Canadian government or a Canadian-controlled entity. It does not, however, include a corporation deemed to be a Canadian pursuant to s-s. 26(3).

Hence, the principal concept relating to control is the holding of "voting interests" which, with respect to a corporation, is defined to mean a "voting share". This, in turn, is defined to mean:"17

... a share in the capital of a corportion to which is attached

(a) a voting right ordinarily exercisable at meetings of shareholders of the corporation, and

(b) a right to receive a share of the profits or to share in the assets of the corporation on dissolution or both.

This definition of voting share goes further than the concept in the FIR Act of "shares of the corporation to which are attached voting rights ordinarily exercisable at meetings of shareholders of the corporation" and attempts to prevent circumvention of the law by totally separating rights to the equity from rights to the vote.

In contrast to the FIR Act definition of non-eligible person, jurisdiction of incorporation is totally irrelevant in determining whether an entity is Canadian-controlled for purposes of the ICA. More importantly, control in fact through a trust or a contract or any other method other than the ownership of a voting interest is also irrelevant. The significance of this distinction can be illustrated with reference to the case of Attorney General of Canada v. KSC, Ltd., ${ }^{18}$ in which the respondent's new business investment proposal had been twice disallowed, following which its American parent agreed to sell fifty-one per cent of the voting shares to its Canadian sales manager. The Attorney General apparently argued that the American parent had, through such things as loan agreements and management and pricing policies, control in fact of the respondent and, accordingly, applied for an order rendering its investment nugatory. The Federal Court of Canada held that the share ownership in the hands of the resident Canadian was conclusive on the issue of control of the respondent company. This is presumably a case which the Attorney

17. Id.

18. (1983) 22 B.L.R. 32. 
General would not even consider raising under the ICA, since the respondent would clearly be a Canadian-controlled entity under s-s. 26(1) because a Canadian individual owned a majority of its voting interests.

Under the FIR Act, a corporation was itself a non-eligible person if it was controlled by a group of persons any member of which was a noneligible individual or a non-eligible government or agency thereof. The situation where the group provision most frequently had unexpected consequences was where some of the shareholders of a corporation (usually one whose shares were not publicly traded) were parties to a shareholders' agreement. Depending upon how extensive were the provisions of that shareholders' agreement, those shareholders might be acting in concert and thereby constitute a group. If one of them was noneligible, he could contaminate the entire corporation. The provisions of each shareholders' agreement had to be looked at carefully to determine whether the parties to the agreement were acting as a group in relation to the control of the corporation. For example, take the situation of a closely-held corporation with only two shareholders, a resident Canadian who owned fifty-one per cent of the voting shares and an American who owned forty-nine per cent of such shares, and they had entered into an extensive shareholders' agreement, had agreed to the composition of the board of directors, the dividend policy, and so on. Under the FIR Act, the corporation was controlled by a group, one of the members of which was a non-eligible person, and the corporation itself was a non-eligible person. Under the ICA, the analysis would be simpler and the result different. The situation would fall into the first "catch-basin" in paragraph 26(1)(a), namely, one Canadian would own a majority of the voting interests of the entity and it would be deemed to be Canadian-controlled, notwithstanding the shareholders' agreement.

Subsection 26(6) of the ICA provides that where two persons own equally all of the voting shares of a corporation and at least one of them is a non-Canadian, the corporation is not a Canadian-controlled entity. This enacts a position which the Canadian government had previously taken, with questionable validity, with respect to fifty-fifty ownership situations under the FIR Act.

There are certain supplementary rules ${ }^{19}$ to assist in determining, for the series of "catch-basins" in s-s. 26(1), who owns voting interests in an entity. Where voting interests of an entity are owned by a partnership, a trust (except one not controlled in fact through ownership interests) or a joint venture, those voting interests are deemed to be owned by the partners, beneficiaries or members of the joint venture, as the case may be, in the same proportion as their respective ownership interests in the assets of the partnership, trust or joint venture. Accordingly, for example, if all of the shares of a corporation carrying on a Canadian business were owned by a partnership, in which there were three equal partners, two being Canadians and one being foreign, the voting shares of the corporation would be deemed to be held as to two-thirds by Canadians and as to onethird by a non-Canadian. The corporation would be deemed to be a Canadian-controlled entity pursuant to paragraph $26(1)(c)$, i.e., a ma-

19. Supra n. 1, s. 27. 
jority of the voting interests would be owned by Canadians and it could be established that the corporation was not controlled in fact through the ownership of its voting interests by non-Canadians. By contrast, under the FIR Act this corporation would have been controlled by a group of persons, one of the members of which was a non-eligible individual, and, accordingly, the corporation would itself have been a non-eligible person.

Any voting shares of a corporation that are issued to bearer are deemed to be owned by non-Canadians unless the contrary is established. Where voting interests of an entity are held by individuals each of whom holds not more than one per cent of the total number of voting interests of such entity, the Minister shall, in the absence of evidence to the contrary, accept as evidence that those voting interests are owned by individuals who are Canadians, a statement from such entity that, according to its records, such individuals have addresses in Canada.

Subsections 26(3), (4) and (5) of the ICA provide as follows:

(3) Where, after considering any information and evidence submitted by or on behalf of a corporation incorporated in Canada the voting shares of which are publicly traded in the open market, the Minister is satisfied that, with respect to the corporation,

(a) the majority of its voting shares are owned by Canadians,

(b) four-fifths of the members of its board of directors are Canadian citizens ordinarily resident in Canada,

(c) its chief executive of ficer and three of its four most highly remunerated of ficers are Canadian citizens ordinarily resident in Canada,

(d) its principal place of business is located in Canada,

(e) its board of directors supervises the management of its business and affairs on an autonomous basis without direction from any shareholder other than through the normal exercise of voting rights at meetings of its shareholders, and

(f) the circumstances described in paragraphs (a) to (e) have existed for not less than the twelve month period immediately preceding the submission of the information and evidence,

the corporation shall be deemed to be a Canadian for the purpose of making any investment described in subsection 14(1), except an investment falling within a prescribed specific type of business activity that, in the opinion of the Governor in Council, is related to Canada's cultural heritage or national identity, and the Minister shall so notify the corporation.

(4) The Minister may accept, as proof of the circumstances described in paragraphs 3(e) and (f), a written statement by the corporation to that effect, signed by all the members of its board of directors.

(5) If the material facts submitted by or on behalf of the corporation are accurate, the presumption under subsection (3) applies, from the date of the notification by the Minister referred to in that subsection, for so long as those material facts remain substantially unchanged or for two years from the date of that notification, whichever period is shorter.

This special deeming provision is designed to encourage a degree of Canadianization of certain public companies in which foreign corporations have large shareholdings. The residence of Canadian citizens has reappeared as a relevant factor in this provision. The residence of the corporation, in the sense of the location of its principal place of business, has become relevant. In addition, in this one instance, the distinction between publicly and privately traded shares is relevant. It must be borne in mind that it is not enough for the corporation in question to meet the tests objectively; the Minister responsible for the administration of the ICA himself must be satisfied that the tests have been met and that they 
have been met for not less than the twelve month period immediately preceding the submission of the information and evidence to him. It should also be noted that this special deeming provision cannot be utilized to escape from the review provisions relating to investments in businesses that are related to Canada's cultural heritage or national identity.

\section{E. UNINCORPORATED ENTITIES}

As mentioned above, the FIR Act handled investments by unincorporated entities such as partnerships and joint ventures in a rather unsatisfactory way. It simply provided that every "group of persons any member of which is a non-eligible person" that proposed to acquire control of a Canadian business enterprise or to establish a new business in Canada must file a notice. ${ }^{20}$ There was no definition of "group", but it clearly included a partnership, a joint venture and a trust.

Accordingly, a direct investment in Canada by a partnership or joint venture, any member of which was a non-eligible person, no matter how minor his interest, was reviewable. This produced anomalous results. On the one hand, an investment by a partnership or joint venture in which non-eligible persons held only one percent of the equity was reviewable. On the other hand, a corporation whose shares were publicly traded was not a non-eligible person, even if a majority of its shares were held by non-eligible persons, if it was nevertheless controlled in fact by resident Canadians. Accordingly, its investments in Canada were not subject to review. Clearly, partnerships and other unincorporated forms of business organizations were at a disadvantage.

The ICA defines an "entity" to include a "partnership", "trust" or "joint venture". ${ }^{21}$ Accordingly, to determine the status of such unincorporated entities, one simply proceeds to the series of "catch-basins" in s-s. 26(1) in the same way as one does for a corporation, as described above.

For example, limited partnerships, a common form of unincorporated business organization, gave rise to many questions under the FIR Act. Under ordinary partnership law each partner has a degree of influence, if not outright veto, over partnership decisions. On the other hand, the provincial laws in Canada governing limited partnerships generally provide that the general partners manage the partnership and have unlimited liability whereas limited partners are basically only financial partners who do not participate in the control and management of the partnership. Accordingly, it was of ten argued that the status of only the general

20. Supran. 2, ss. 8(1) and (2).

21. Supra n. 1, s. 3. Of those three terms, only a joint venture is, in turn, defined as:

“. . . an association of two or more persons or entities, where the relationship among those associated persons or entities does not, under the laws in force in Canada, constitute a corporation, a partnership or a trust and where, in the case of an investment to which this Act applies, all the undivided ownership interests in the assets of the Canadian business or in the voting interests of the entity that is the subject of the investment are or will be owned by all the persons or entities that are so associated." 
partners should be looked at to determine the status of the partnership. FIRA issued Interpretation Note No. 3 in an attempt to deal with this issue, which should disappear under the ICA. The only question under the ICA will be the ownership of "voting interests" which, with respect to a partnership, trust or joint venture, is defined in s. 3 to mean:

... an ownership interest in the assets thereof that entitles the owner to receive a share of the profits and to share in the assets on dissolution.

The assimilation of trusts to partnerships and joint ventures may not be without its difficulties, but this will be eased by a specific exception. This is that, where it can be established that a trust is not controlled in fact through the ownership of its voting interests, then the "catchbasins" in s-s. 26(1) do not apply and the trust is a Canadian-controlled entity where two-thirds of its trustees are Canadians. ${ }^{22}$ Most trusts will presumably fall into this "exception".

\section{REVIEWABLE TRANSACTIONS}

\section{A. ACQUISITIONS}

While the basic concepts relating to reviewable acquisitions of businesses in Canada have not changed substantially in the ICA, its technical definitions have changed totally. Accordingly, it is necessary for the lawyer to disregard the definitions in the FIR Act and learn an entirely new set of definitions.

The FIR Act applied to "acquisitions of control" of "Canadian business enterprises". A "Canadian business enterprise" was defined to mean a business that was either a "Canadian business" or a "Canadian branch business". ${ }^{23}$ These two definitions had significance from the technical standpoint of how an acquisition of control took place. In particular, they facilitated the Parliamentary intention to avoid reviewing takeovers of foreign corporations carrying on business in Canada through a branch. This was accomplished by defining the "Canadian branch business" as a business carried on in Canada by a corporation incorporated outside of Canada that maintained one or more establishments in Canada to which employees of the corporation ordinarily reported for work. A "Canadian business" was defined, in effect, to mean a business carried on in Canada by anyone else, i.e., an individual who was either a Canadian citizen or a Canadian resident (although not non-eligible individuals), a corporation incorporated in Canada that maintained one or more establishments in Canada to which its employees ordinarily reported for work or any number of such individuals or corporations, or any combination thereof. There were two methods of acquiring control of a Canadian business enterprise, namely, in the case of a "Canadian business", by the acquisition of the voting shares of a corporation incorporated in Canada or by the acquisition of all or substantially all of the property used in carrying on the business in Canada; in the case of a "Canadian branch business", by the acquisition of all or substantially all of the property used in carrying on the business

22. Id. s. 26(3).

23. Supra n. 2, s. 3(1). 
in Canada, but not, in effect, by the acquisition of the foreign corporation carrying on such business. ${ }^{24}$

In the case of either a "Canadian business" or a "Canadian branch business", one had to have regard to the definition of "business", which definition "includes any undertaking or enterprise carried on in anticipation of profit"'.25 It was also essential, in the case of a business carried on by a corporation, that it have one or more establishments in Canada to which employees of the corporation employed in connection with the business ordinarily reported for work. These two basic definitions led to three fundamental criteria of a target business whose acquisition was reviewable:

(a) the FIR Act was concerned with acquisitions of businesses rather than simply property;

(b) a corporate business had to have an actual physical presence in Canada; the FIR Act was not concerned with takeovers of corporations per se; and

(c) corporate businesses had to have at least two employees ordinarily reporting for work.

The ICA is structured differently. The definition of "Canadian business enterprise" has been dropped. There is a definition of "Canadian business", but it is totally different from that in the FIR Act. It does not relate to the character or status of the person or persons carrying on the business. Consequently, there is no need for a definition of "Canadian branch business". The Parliamentary objective of avoiding the review of takeovers of foreign corporations carrying on business in Canada through a branch is achieved otherwise.

The ICA contains a definition of "business", but it has been expanded from that contained in the FIR Act to read as follows: ${ }^{26}$

"business" includes any undertaking or enterprise capable of generating revenue and carried on in anticipation of profit. [Emphasis added.]

The ICA retains the provisions of the FIR Act under which a Canadian business which is carried on partly in Canada and partly elsewhere will be deemed to be carried on in Canada so that it is a target whose acquisition is reviewable. ${ }^{27}$ Similarly, as with the FIR Act, a part of a business that is capable of being carried on as a separate business is a Canadian business if the business of which it is a part is a Canadian business. ${ }^{28}$

Subsection 14(1) of the ICA sets forth the major provision of that Act. It provides that certain described investments by non-Canadians are reviewable. It refers to investments "to acquire control of a Canadian business in any manner described" in the various paragraphs of s-s. $28(1)$. This is further circumscribed by reference to "circumstances" described in s-s. 14(2) and "limits" set out in s-ss. 14(3) and (4).

24. Id. s. 3(3)(a).

25. Id. s. $3(1)$.

26. Supra n. 1, s. 3.

27. Id. s. 31(1); Supran. 2, s. 3(6)(f).

28. Supra n. 1, s. 31(2); Supra n. 2, s. 3(6)(g). 
Hence, first one must look at the definition of a "Canadian business", which is: ${ }^{29}$

... a business carried on in Canada that has

(a) a place of business in Canada,

(b) an individual or individuals in Canada who are employed or self-employed in connection with the business, and

(c) assets in Canada used in carrying on the business.

Comparing this to the definition of "Canadian business enterprise" in the FIR Act, we see that:

(a) As in the FIR Act, there must be a business, and not simply property, to constitute a subject matter of a reviewable acquisition. In fact, the test of "carried on in anticipation of profit" has been further qualified by the test of "capable of generating revenue".

(b) Like the FIR Act, the ICA is not concerned with takeovers of corporations per se.

(c) However, with the adoption of the more general concept of "an individual or individuals" who are "employed or self employed", it would appear that a corporate business' takeover would be reviewable even if it had only one employee in Canada. Furthermore, the employee need not be an employee of the entity carrying on the business; he need only be employed "in connection with the business".

If there is a "Canadian business" whose acquisition is contemplated, the next question is whether there is an acquisition of control within the meaning of the rules established in s-s. 28(1) of the ICA. However, one must always read s-s. 28(1) in relation to s-s. 14(1) because the latter, in turn, relates the particular method of acquisition to the asset tests which are the "circumstances" and "limits" described in s-ss. 14(2), (3) and (4) and which provide the thresholds of economic significance.

Under the FIR Act, there were two methods of acquiring the control of a Canadian business enterprise, namely: ${ }^{30}$

(a) by the acquisition of all or substantially all of the property used in carrying on the business in Canada, and

(b) in the case of a business carried on by a corporation incorporated in Canada, by the acquisition of its voting shares or those of its foreign parent.

The methods of acquisition of control under the ICA are similar but not identical. Essentially, subsection 28(1) provides for three methods of acquiring control of a Canadian business:

(a) by the acquisition of all or substantially all of the assets used in carrying on the Canadian business,

(b) in the case of a business carried on by a corporation incorporated in Canada, by the acquisition directly or indirectly of its voting shares, and

(c) by the acquisition of voting interests of an entity that is carrying on the Canadian business itself (so long as it is not a corporation) or controls, directly or indirectly, another entity carrying on a Canadian business.

What has been added is the concept of acquisition of control through "voting interests" in the case of unincorporated business organizations.

29. Supra n. 1, s. 3.

30. Supran. 2, s. 3(3)(a). 
This is the same concept used to determine the status of foreign investors and, as previously described, ${ }^{31}$ means, with respect to a partnership, trust or joint venture, an ownership interest in the assets thereof that entitles the owner to receive a share of the profits and to share in the assets on dissolution. In other words, acquisition of control of unincorporated businesses can be looked at from the standpoint of acquisition of equity interests rather than, as under the FIR Act, only as acquisition of the assets used in carrying on the business.

The FIR Act contained, with respect to share acquisitions, a series of rebuttable presumptions as to when acquisitions of control of corporations occurred. These presumptions clearly reflected a concept of control in fact although the phrase "in fact" was not used in that context, as it was in the definition of "non-eligible person". These presumptions ${ }^{32}$ were that acquisition of control of a corporation resulted from the acquisition by any person or group of persons of shares of a corporation to which were attached:

(a) Five per cent or more of the voting rights ordinarily exercisable at meetings of shareholders of the corporation, in the case of a corporation whose shares were publicly traded, or

(b) Twenty per cent or more of the voting rights ordinarily exercisable at meetings of shareholders of the corporation, in the case of a corporation whose shares were not publicly traded.

Furthermore, any acquisition by any person or group of shares of a corporation to which were attached more than fifty per cent of the voting rights ordinarily exercisable at meetings of shareholders of the corporation was deemed to constitute the acquisition of control, unless the person or group had, at the time of the acquisition, control in fact of the corporation. ${ }^{33}$

Such presumptions constituted very low thresholds and placed upon an acquiror of shares an obligation to rebut the presumption at law. The underlying assumption was that control of the decisions to be made by the board of directors or other governing body of the corporation constituted control of the corporation. In most cases, such power would reside with one or more shareholders who, through their voting power, had the power to control the election of the majority of the members of the board of directors or other governing body. However, each case had to be looked at on its own facts. For example, if someone other than the acquiror or the person from whom he had acquired his shares, or his vendor, had acquired control in fact previously, perhaps as a result of application of precisely those low thresholds, then the subject acquisition could presumably be shown not to constitute an acquisition of control in fact.

Subsection 28(3) of the ICA establishes certain presumptions regarding acquisitions of control, some of which are materially more liberal than those in the FIR Act. An acquisition of a majority of the voting interests of an entity, including a corporation, is deemed to be an acquisition of control under the ICA. An acquisition of less than one-third of the voting shares of a corporation is deemed not to be an acquisition of control.

31. Supra text following note 21 .

32. Supra n. 2, s. 3(3)(c).

33. Id. s. 3(3)(d). 
An acquisition of less than a majority, but one-third or more, of the voting shares of a corporation is presumed to be an acquisition of control unless it can be established that on the acquisition the corporation is not, in fact, controlled by the acquiror through the ownership of voting shares.

For entities other than corporations, i.e., partnerships, trusts or joint ventures, the rule under the ICA is even less onerous, as an acquisition of less than a majority of the voting interests is deemed not to be an acquisition of control.

Accordingly, there are really two systems for acquiring control of entities in the ICA:

\section{Acquisition of Corporations}

Majority of voting interests - Deemed Acquisition

Less than one-third - Deemed Non-Acquisition

Between one-third and majority - Rebuttable Presumption of Acquisition

Acquisition of Unincorporated Entities

Majority of voting interests - Deemed Acquisition

Less than majority - Deemed Non-Acquisition

Instead of always dealing with the question of control in fact, with a series of rebuttable presumptions, as in the FIR Act, we have in the ICA a series of deeming provisions, with only one rebuttable presumption. That applies in the acquisition of corporate shares in the range of onethird to one-half but, within that range, the question of control in fact will presumably be similar to the question as it occurred in the FIR Act. These deeming provisions do not distinguish between publicly and privately traded shares.

Indirect acquisitions of control of Canadian corporations carrying on business in Canada are, subject to the new thresholds, reviewable under the ICA as they were under the FIR Act, although the drafting that accomplishes this is different. Under the FIR Act, an acquisition of control of a corporation incorporated elsewhere than in Canada and carrying on business in Canada was not reviewable; it was simply not one of the methods of acquisition of control within the meaning of s-s. 3(3) of the FIR Act. On the other hand, the acquisition of a foreign corporation that had a Canadian subsidiary carrying on business in Canada was reviewable pursuant to s-s. 3(3) because of an interpretation of that provision in relation to paragraph 3(6)(h) of the FIR Act. This interpretation did, however, provoke some controversy and, it is fair to say, the Parliamentary intention was not entirely clear.

It seems clear from the structure of s-s. 28(1) of the ICA that the acquisition of control of a foreign corporation with a branch business in Canada is not reviewable, that the acquisition of any other entity with a branch business in Canada is reviewable and that the acquisition of an entity that controls another entity in Canada carrying on the Canadian business is reviewable. In other words, acquisitions of partnerships and other unincorporated entities with a Canadian branch are reviewable, as are indirect acquisitions of Canadian subsidiaries. Acquisitions of foreign corporations with Canadian branches are not reviewable. 
Insofar as asset acquisitions are concerned, the ICA is the same as the FIR Act. The policy is to review acquisitions of complete businesses and not simply isolated or passive assets. Accordingly, all or substantially all of the assets of a business must be acquired for the ICA to be applicable. The ICA, like the FIR Act, contains no definition of what constitutes "substantially" all the property. There was no jurisprudence on this phrase in the FIR Act, although there has been some jurisprudence on the phrase in Canadian corporation legislation and, to a greater extent, in American corporation legislation. Such jurisprudence is very imprecise, suggesting that the test can be both qualitative and quantitative. ${ }^{34}$ In Interpretation Note No. 6, FIRA stated that where a non-eligible person acquired all of the property essential to the conduct of the transferor's business enterprise, the test of "substantially all" might be met. FIRA stated that, for example, if a non-eligible person acquired the operating property or assets essential to the continuance of a Canadian business enterprise, then, even if those assets amounted to less than fifty per cent of the total properties or assets of that business (the transferor retaining its liquid assets such as cash, promissory notes and investment portfolio), the test of "substantially all" of the property used in carrying on the transferor's business might nevertheless have been met. While it is submitted that this is too liberal an interpretation of the phrase "substantially all", nevertheless, it is clear that once significant assets of a business are proposed to be acquired by a non-Canadian, he must proceed with caution. Assets include both tangible and intangible assets and the manner of calculating the value of the assets is to be prescribed by regulation.

The ICA contains a "step transaction" provision, the first portion of which is virtually identical to that found in the FIR Act. ${ }^{35}$ As a consequence, for example, a non-Canadian who owns twenty-five per cent of the voting shares of a Canadian corporation carrying on a Canadian business at the time the ICA comes into force and who then acquires a further thirty per cent of such voting shares will acquire control of that Canadian business at the time of such further acquisition, notwithstanding that an acquisition of less than one-third of the voting shares of a corporation would not in itself be an acquisition of control. This provision might also, for example, operate to bring within the definition of voting share a share which does not have a voting right when acquired but which subsequently acquires a voting right as the result of a subsequent event or transaction.

The step transaction provision was, however, amended at the committee stage and now goes further than its counterpart in the FIR Act. There is a provision ${ }^{36}$ that where, as a result of more than one transaction or event, no one of which is an acquisition of control within the meaning of s-s. 28(1), an entity carrying on a Canadian business is "controlled in fact through the ownership of voting interests" by a non-Canadian, that nonCanadian is deemed to have acquired control of the entity at the time and

34. The leading case is Gimbel v. The Signal Companies, Inc. 316 A. (2d) 599, confirmed on appeal in $316 \mathrm{~A}$. (2d) 619.

35. See I.C.A., supra n. 1, s. 29(1); F.I.R. Act, supra n. 2, s. 3(8).

36. Supra n. 1, s. 29(2). 
in the manner of the latest of such transactions or events. There appears to be a question of whether this amendment goes so far as to override the structure of s-s. 28(1) and to reintroduce an overriding concept of acquisition of control in fact as in the FIR Act. It is understood that this was not the intention of the government and it may be that an opinion to such effect could be obtained from the Minister or Investment Canada, if necessary.

However, the significance of this step transaction provision is well illustrated when it is read in conjunction with s-s. 28(2) which sets forth certain rules and presumptions respecting the control of entities. The latter ensures that the direct and indirect holdings of an acquiror are aggregated for the purposes of determining whether there has been an acquisition of control. Accordingly, where, as a result of more than one transaction or event no one of which is an acquisition of control under s-s. 28(1), an entity carrying on a Canadian business becomes controlled in fact through the ownership of voting interests by a non-Canadian, that non-Canadian is deemed to have acquired control of the entity at the time and in the manner of the latest of such transactions or events. Consequently, if a non-Canadian corporation, which owns thirty per cent of the voting shares of a Canadian corporation carrying on a Canadian business, establishes a wholly-owned subsidiary which purchases a further thirty per cent of the voting shares of the target corporation, there is an acquisition of control.

The acquisition of a contingent right to acquire either voting interests of an entity or assets used in carrying on a business is not deemed to be an acquisition of those voting interests or assets as it is under the FIR Act. ${ }^{37}$ This will avoid many of the more onerous applications of the FIR Act. However, the non-Canadian investor may treat an absolute right under a written contract to acquire voting interests or assets as if exercised and as if he owns the voting interests or assets that are the subject of that right. ${ }^{38}$ This would, for example, permit a foreign investor, who, with a Canadian, is establishing a Canadian corporation to carry on a business in Canada, to treat an unfettered option to purchase the Canadian's shares as being exercised, from the outset, thus avoiding any subsequent review or notice upon such an exercise.

One presumably unintended result of the deeming provisions in s-s. 28(1) of the ICA is that a non-Canadian who acquires a majority of the voting interests of an entity carrying on a Canadian business is deemed to have acquired control even if he already had control in fact; there is no provision similar to paragraph 3(3)(d) of the FIR Act. This would appear to be unfair to a foreign investor who had already obtained an allowance under the FIR Act at the time of his acquisition of control in fact. It is hoped that Investment Canada may be prepared to provide opinions to the effect that the transaction would not be reviewable under the ICA, so that the foreign investor would not suffer a form of "double jeopardy".

37. Supra n. 2, s. 3(6)(c).

38. Supran. 1, s. 30(1). 


\section{B. ECONOMIC THRESHOLDS}

One of the most important changes to the law made by the ICA is the introduction of major thresholds of economic significance, below which takeovers by non-Canadians are not reviewable. Under the FIR Act, there was the somewhat pitiful exemption for the takeover of a business whose gross assets did not exceed 250,000 dollars and whose gross revenues did not exceed three million dollars for the last completed fiscal period, if such business was "related" to a business already carried on in Canada by the non-eligible purchaser. ${ }^{39}$ By virtue of s-s. 14(3) of the ICA, a takeover of a Canadian business is only reviewable if its assets are valued at five million dollars or more. This threshold ignores the gross revenues of the business and whether it is related to some other business already carried on in Canada by the non-Canadian purchaser. The calculation of the value of "assets" will be prescribed in regulations which have not yet been tabled.

In addition, where a non-Canadian acquires control of a foreign corporation that controls, directly or indirectly, an entity in Canada carrying on the Canadian business, the transaction is not reviewable unless the value of the assets of the entity carrying on the Canadian business is fifty million dollars or more..$^{40}$ However, this higher threshold does not apply if the value of the assets of the entity carrying on the Canadian business and of all other entities in Canada the control of which is acquired, amounts to more than fifty per cent of the value of the assets of all entities which are acquired in the transaction. ${ }^{41}$ In other words, there is a fifty million dollar threshold on an indirect corporate acquisition of a Canadian business so long as that Canadian business is not the true target of the transaction.

\section{EXEMPTIONS}

There are a number of exemptions from the definitions of acquisition of control in the ICA. Generally speaking, they are very similar to those contained in the FIR Act, but they tend to be more clearly and specifically drafted and, in addition, they are set out separately in "Part II" under the heading "Exemptions". They are as follows:

\section{Securities Dealers}

There is the identical exemption for the brokerage and underwriting functions of securities dealers to that in the FIR Act. ${ }^{42}$

\section{Venture Capitalists}

There is the identical exemption for foreign venture capital companies, provided that they comply with certain terms and conditions to be

39. Supra n. 2, s. 5(1)(c) and s. 31(3).

40. Supra n. 1, s. 14(1)(d).

41. Id.s. 14(1)(c).

42. Supran. 1, s. 10(1)(a); supran. 2, s. 3(3)(ii). 
specified by the Minister. ${ }^{43}$ Presumably, these will be the same as applied under the FIR Act.

\section{Mortgagees, etc.}

There is a specific exemption for the acquisition of control of a Canadian business in connection with the realization of security granted for a loan or other financial assistance and not for any purpose related to the provisions of the ICA. ${ }^{44}$ This can be contrasted with the provisions of the FIR Act, which protected foreign mortgagees and pledgees at the time they took their security; this was required because, under the FIR Act, the acquisition of a contingent right to acquire property was deemed to constitute the acquisition of the property, ${ }^{45}$ which is not the case under the ICA. Under the latter, it is only at the time of realization of the security that the exemption is required. In addition, the ICA makes it clear that FIRA's restrictive interpretation of the provision of the FIR Act is no longer the policy. In Interpretation Note No. 4, FIRA had indicated three limitations to the FIR Act's protection:

(a) The loan had to be bona fide. This is clearly the case under the ICA as well.

(b) FIRA had given the word "loan" a strict interpretation, i.e., "money borrowed with a promise to repay", and, accordingly, in FIRA's view not all debtor-creditor relationships were necessarily covered by the exemption. For example, FIRA stated that the taking of security to secure outstanding trade debts was not considered to be exempt from review. On the other hand, the ICA has added the words "or other financial assistance", which presumably negates this restriction.

(c) FIRA had taken the view that the security must be given by the person to whom the loan was advanced. While there was no apparent justification for this interpretation, nevertheless the broader language of the ICA provision could not, it is submitted, in any way be interpreted as being so limited. In other words, the exemption would apply to realization of security granted by a guarantor or other third party.

\section{Financing}

The acquisition of control of a Canadian business for the purpose of facilitating its financing and not for any purpose related to the provisions of the ICA is exempt, on the condition that the acquiror divest himself of control within two years after it is acquired or within such longer period as is approved by the Minister. ${ }^{46}$

\section{Corporate Reorganizations}

Corporate reorganizations are clearly and completely exempted in paragraph $10(1)(e)$ of the ICA where the ultimate control in fact of the

\footnotetext{
43. Supra n. 1, s. 10(1)(b); supra n. 2, s. 3(3)(b)(iii).

44. Supran. 1, s. 10(1)(c).

45. Supra n. 2, s. 3(6)(d) and (d.1).

46. Supra n. 1, s. 10(1)(d).
} 
Canadian business, through the ownership of voting interests, remains unchanged The only specific exemption in the FIR Act had been that relating to amalgamations, although "upstream" share transfers were also exempted through an interpretation of paragraph $3(6)(h)$, i.e., that a parent company was deemed to be carrying on the business of its subsidiaries itself. This lack of a full exemption had necessitated the issuance by FIRA of Corporate Reorganization Guidelines. ${ }^{47}$ Not only was there at least some question about their authority, but they were unnecessarily restrictive, because reorganizations of corporate groups which involved a transfer of shares or assets to a corporation incorporated outside of Canada were not automatically exempt. This limitation does not exist under the ICA.

\section{Government Vendors}

The acquisition of control of a Canadian business carried on by an agent of a federal or provincial government, or by a Crown corporation, is exempt in a manner similar to that in the FIR Act. ${ }^{48}$

\section{Tax-exempt Vendors}

Similarly, sales to non-Canadians by certain tax-exempt municipal or provincial corporations are also ICA exempt. ${ }^{49}$

\section{Banks}

Any transaction to which s. 307 of the Bank Act (Canada) applies is exempt from the provisions of the ICA. ${ }^{50}$ This does not change the situation whereby, by s. 307 of the Bank Act, the FIR Act did not apply to such transactions.

\section{Involuntary Acquisitions}

The ICA specifically exempts the involuntary acquisition of control of a Canadian business on the devolution of an estate or by operation of law. ${ }^{51}$ Under the FIR Act, there was no such specific exemption.

\section{Real Estate}

The government made an ultimately unsuccessful attempt to improve upon the difficulties in applying the FIR Act to acquisitions of real estate or immovables. Under the FIR Act, the underlying question was always whether a real estate transaction involved the acquisition of control of a Canadian business enterprise or the establishment of a new business in Canada, or was simply a passive investment. The only specific provision relating to real estate provided that a person who acquired and held land, whether with the intention of disposing thereof within a fixed or determinable period of time or otherwise, did not, by reason only of the

47. The Canada Gazette. Part I, Vol. 109, No. 17 (April 26, 1975), at 1570.

48. Supran. 1, s. 10(1)(f); supra n. 2, s. 5(1)(a).

49. Id., s. 10(1)(g); s. 5(1)(b).

50. Supra n. 1, s. $10(1)(h)$. This is a bigger exemption than it looks.

51. Id. s. $10(1)(\mathrm{i})$. 
holding of the land and the expenditure of funds to maintain the land in the condition in which it was acquired or to improve the land for its own use and enjoyment, carry on a business. ${ }^{52}$ In other words, it was clear that, in such a case, all that was involved was a passive investment in land and not the acquisition of a business. However, most acquisitions were not so easy to analyze from this standpoint. It seemed clear that the acquisition of a farm would, for example, normally be the acquisition of a Canadian business enterprise because a farm is a business. On the other hand, investments in commercial real estate were more difficult to characterize. The ownership of an apartment building which was managed by a Canadian might seem like a passive investment. On the other hand, ownership of a shopping centre might seem more like a direct investment in a business. But what if it were subject to a net lease to a Canadian who managed everything and paid all operating costs? The Minister issued guidelines in an attempt to clarify this situation, ${ }^{53}$ but these were only moderately helpful.

As originally introduced into the House of Commons by the government, the ICA contained an exemption for the acquisition, subject to such terms and conditions as might be fixed by the Minister, of control of a Canadian business the revenue of which was generated primarily from the rental of the real property acquired in the same transaction. ${ }^{54}$ At the committee stage, the government deleted the reference to "primarily", which seemed to indicate some nervousness about so broad an exemption. The government also introduced an additional exemption for the acquisition of control of a Canadian business the revenue of which was generated from farming carried out on the real property acquired in the same transaction. ${ }^{55}$ This exemption was presumably in recognition of the primary constitutional responsibility of the provinces.

However, on third reading in the House of Commons the so-called "Axworthy amendment" was passed by the combined votes of the Liberal and New Democratic parties. ${ }^{56}$ This amendment deleted the principal real property exemption, much to the embarassment of the government. It is expected that the government will issue guidelines in an attempt to clarify the treatment of real estate transactions and, ultimately, that it may reintroduce the appropriate amendment to the ICA. In the meantime, however, the application of the law to such transactions will be more difficult than ever. One will be forced to resort to first principles, i.e., does an investment in real estate constitute an acquisition of control of a Canadian business?

\section{Insurance Company Portfolios}

Investments in Canadian businesses by insurance companies have been largely exempted. ${ }^{57}$

52. FIR Act, s. 3(9).

53. The Canada Gazette, Part I, Vol. 108, No. 14 (April 6, 1974) at 1201.

54. Supran. 1, s. 10(1)(j).

55. Id. s. $10(1)(1)$.

56. Motion No. 24 (Mr. Axworthy) approved June 6, 1985.

57. Supran. 1, s. 10(1)(k). 


\section{CULTURAL HERITAGE OR NATIONAL IDENTITY}

A rather eccentric aspect of the ICA is the way it deals with business activities that are related to "Canada's cultural heritage or national identity". Notwithstanding the general dropping from review of the establishment of new businesses, and the creation of substantial thresholds below which acquisitions are non-reviewable, s. 15 of the ICA provides for the potential review of:

(a) an investment by a non-Canadian to establish a new Canadian business that is related to Canada's cultural heritage or national identity; and

(b) an investment by a non-Canadian to acquire control of a Canadian business that is related to Canada's cultural heritage or national identity, regardless of size and of whether such business is related to an existing business of the non-Canadian.

Section 15 of the ICA provides that such an investment is reviewable if:

(a) it falls within a prescribed specific type of business activity that, in the opinion of the Governor in Council, is related to Canada's cultural heritage or national identity; and

(b) the Governor in Council, where he considers it in the public interest on the recommendation of the Minister, issues an order for review.

Subsections 35(2) and (4) provide that any regulations made for the purpose of prescribing such specific types of business activity must be laid before each House of Parliament and that, with the exception of those which come into force upon the proclamation of the ICA, such regulations shall not come into force until at least sixty days after they are made. Hence, the foreign investor will always know before he makes his investment whether his proposed investment is one that, in the opinion of the government, is related to Canada's cultural heritage or national identity. In addition, his investment is only reviewable if an Order in Council specifically dealing with his proposed investment is issued. This must be done within 21 days after receipt by the Minister of notification by the investor of his proposed investment.

Accordingly, there should be no fear that this exception will provide some sort of avenue for unfair and arbitrary action on behalf of the government. It also seems clear that the government could not prescribe specific types of business activity which are important because of their economic importance. It is submitted that national "identity" does not include national "security" and, to be fair, the Honourable Sinclair Stevens has made this clear. ${ }^{58}$

58. Mr. Stevens has indicated that the business activities which will be prescribed at the time of coming into force of the ICA are as follows:

1. Publication, distribution or sale of books, magazines, periodicals or newspaper in print or machine readable form.

2. Production, distribution, sale or exhibition of film or video products.

3. Production, distribution, sale or exhibition or audio or video music recordings.

4. Publication, distribution or sale of music in print or machine readable form. 
It should be remembered that the special provision, in s-s. 26(3), deeming certain public companies to be Canadian, does not apply to investments with such cultural heritage or national identity ramifications.

\section{E. OIL AND GAS INDUSTRY}

Particular technical problems arose under the application of the FIR Act to the oil and gas industry, and these have been commented upon by those more familiar with that industry than the author. ${ }^{59}$ Generally speaking, these problems reflected the prevalence in that industry of a myriad of ways to combine interests and spread risks. This gave rise to many questions of who controlled a company, of whether a new group of persons had been formed to carry out a particular activity and of whether the acquisition of certain oil and gas rights constituted the acquisition of a business. In 1976, FIRA published the "Guidelines Concerning Acquisitions of Interests in Oil and Gas Rights" which of fered assistance on some, but not all, of these problems. ${ }^{60}$

It is to be hoped that fewer problems will remain under the ICA. For one thing, the "group" concept is gone, replaced with that of an "entity". Whether an entity is not Canadian-controlled and, therefore, is a non-Canadian for purposes of the ICA, will be determined by reference to the previously-discussed rules in $\mathrm{s}$. 26 . These relate solely to control through the ownership of voting interests or, failing that, the status of a corporation's board members or a limited partnership's general partners. Other methods of control of an entity, such as through a contract, are no longer relevant for the purpose of determining the status of an investor.

As to whether a proposed acquisition by a foreign-controlled investor is reviewable under the ICA, the new definition of "Canadian business" must be considered. First, as previously noted, a "business" has been redefined to include the test that the undertaking or enterprise be "capable of generating revenue". This does not, of course, imply that the property must be self-sustaining. Furthermore, the definition of "Canadian business" has been redefined to make it clear that the employees need not be employees of the specific entity which carries on or owns the business; the reference is to a business that has "an individual or individuals in Canada who are employed or self-employed in connection with the business". Hence, the employees could be those of a third party contractor.

It is understood that the government will be issuing new guidelines or interpretation notes under the ICA dealing with the question of what, in relation to the oil and gas industry, constitutes a business whose acquisition is reviewable. Presumably these will reflect FIRA's more mature judgement in its later years that it is only at the development stage that the question arises.

59. See H.A. Jacques and C.A. Rae, "FIRA and the Oil and Gas Industry", Foreign Investment Review Law in Canada, edited by J.M. Spence and W.P. Rosenfeld (1984), at 219 et seg.

60. These were published by the Foreign Investment Review Agency on January 5, 1976 but never Gazetted. 


\section{THE REVIEW PROCESS}

\section{A. MAJOR CHANGES}

There are several major changes to the review process under the ICA from that under the FIR Act:

(a) Under the ICA, the Minister responsible for the Act will make the decision whether to allow an investment, ${ }^{61}$ whereas, under the FIR Act, the decision was made by the entire federal cabinet.62 Presumably, this will change somewhat the dynamics of the process and, in particular, will increase the importance of the Minister responsible for the Act.

(b) Partly because of deletion of a level of decision-making, the length of time to review an investment proposal has been reduced. Under the FIR Act, the basic assumption was that an application would take sixty days to review, this being the period of time beyond which, if no decision were made, an application was deemed to be allowed. ${ }^{63}$ However, under the FIR Act, that period could be unilaterally extended indefinitely by the government, simply by issuing a notice under s-s. 11(1) of the FIR Act. Under the ICA, as we shall see, the basic assumption is that applications will be reviewed within forty-five days. While this can be extended by the Minister, it cannot be extended beyond 105 days without the consent of the applicant. This amendment is not nearly as dramatic as it would have been prior to the administrative reforms implemented by FIRA commencing with the budget of June 1982, pursuant to which the time periods for processing applications under the FIR Act were dramatically reduced.

(c) Under the FIR Act, the statutory test for allowance was whether the government was satisfied that the proposed investment was or was likely to be of "significant benefit to Canada" ${ }^{64}$ Under the ICA, the test is whether the Minister is satisfied that the investment is likely to be of "net benefit to Canada" ${ }^{65}$ Hence, the benefit test has been reduced from one of "significant" benefit to one of which, on balance, there is at least some benefit.

(d) In determining benefit, all of the factors which the government was directed to look at under the FIR Act have been retained but, in addition, two new factors have been added:

(i) The compatibility of the investment with national "cultural" objectives has been included. ${ }^{66}$ While presumably this was added because of the new emphasis on reviewing investments related to matters of cultural heritage or national identity, the fact is that this cultural factor is not limited to such cases. This may significantly expand the range of matters which the government is entitled to consider from those merely economic considerations which it was entitled to consider under the FIR Act ${ }^{67}$

61. Supran. 1, s. 16(1).

62. Supra n. 2, s. 12(1).

63. Id. s. 13(1).

64. Id. S. 12(1).

65. Supra n. 1, s. 21.

66. Id. S. 20(e).

67. Supra n. 2, s. 2(1). See comment in E.J. Arnett, Robert Rueter and Errol P. Mendes, "FIRA and The Rule of Law" (1984) 62 Can. Bar Rev. 121 at 138-139. 
(ii) The government has also been directed to consider the proposed investment's "contribution to Canada's ability to compete in world markets"'. ${ }^{68}$ This contrasts with the rather more parochial nature of the other factors inherited from the FIR Act. Hence, for example, it would now be much easier to argue that a proposed merger was beneficial, notwithstanding its increased economic concentration within Canada, if the benefits of size enabled the resulting merged enterprise to compete better in world markets.

(e) Under the FIR Act, there was nothing to prohibit implementing an investment without an allowance. The only requirement was that notice be given of a proposed investment. ${ }^{69}$ Hence, it was possible, if deemed prudent in the circumstances, to complete a transaction without waiting for a decision of the Cabinet. This has been changed in the ICA, which now provides that, except in certain circumstances, a non-Canadian shall not implement a reviewable investment unless the investment has been reviewed and the Minister is satisfied or is deemed to be satisfied that the investment is likely to be of net benefit to Canada. ${ }^{70}$

This more onerous requirement does not apply:

(i) to indirect corporate acquisitions;

(ii) to investments reviewable pursuant to s. 15 , i.e., where the Governor in Council issues an order for review on the grounds that the investment is related to Canada's cultural heritage or national identity and review is in the "public interest"; or

(iii) where the foreign investor has been notified by the Minister that he is satisfied that a delay in implementing the investment would result in undue hardship to such investor or would jeopardize: the operations of the target business.

The most obvious case for use of this last exception would be where a non-Canadian wishes to make a takeover bid for publicly traded shares.

(f) Under the ICA, an application can never be turned down without the applicant being informed at least once that the Minister is "not satisfied" that the investment is likely to be of net benefit to Canada. ${ }^{71}$ However, as with the FIR Act, there is still no legislative requirement that the government give reasons for a negative decision, which was a major source of criticism of the FIR Act. Furthermore, there is nothing in the ICA which will require the government to disclose to the applicant all the factors being considered by the government, including such things as intervenor bids. The author has commented elsewhere ${ }^{72}$ on the application of the duty of fairness to the FIRA review process and it is submitted that this will apply to the ICA review process as well.
68. Supran. 1, s. 20(f).
69. Supra n. 2, ss. 8(1) and (2).
70. Supra n. 1, s. 16.
71. Id. s. 23(1).
72. Supran. 67. 
[VOL. XXIV, NO. 1

\section{B. THE PROCESS}

As with the FIR Act, the essence of the review process under the ICA is that the federal government will review foreign investments on a case-bycase basis to determine whether they should be allowed. This will resolve itself, in effect, into a bargaining process between the foreign investor and the federal government. However, under the FIR Act, a reviewable transaction had to receive an allowance, or deemed allowance, of the Governor in Council. Under the ICA, the foreign investor needs a notice from the Minister that he is satisfied, or deemed to be satisfied, that the investment is of net benefit to Canada. This will still be a decision based upon considerations of policy rather than law.

The decision-making process under the ICA will be managed by an agency entitled "Investment Canada", 73 whereas under the FIR Act such process was managed by the Foreign Investment Review Agency ("FIRA"). ${ }^{74}$ Under the FIR Act, a foreign investor who proposed a reviewable investment had to file a "notice" in the prescribed form with FIRA. ${ }^{75}$ This notice was commonly referred to as an "application" and the foreign investor as an "applicant". The ICA simply adopts these references for the review process. ${ }^{76}$

While the regulations specifying the information required in an application have not yet been tabled, it is expected that they will be similar to what was required under the FIR Act. However, with the new thresholds of economic significance, it will not be necessary to establish special "small business procedures" and "short form" applications for smaller investments. 77

Under the FIR Act, theoretically the federal government had only sixty days from its acknowledgement of receipt of the application in which to consider it since the FIR Act provided that, if the federal cabinet did not make a decision within sixty days, it was deemed to have allowed the acquisition. However, as noted above, s-s. 11(1) of the FIR Act provided that this period could be extended indefinitely if FIRA advised the applicant that further information was required. Prior to the administrative reforms introduced in late 1982, this process was being abused by sending notices under s-s. 11(1) in almost all cases. Indeed, in the first six months of 1982, the average time taken to review an investment proposal was 155 days! ${ }^{78}$

Under the ICA, the Minister is required to send a notice to the applicant, within forty-five days after the date of receipt of the application, advising that he is satisfied that the investment is likely to be of net benefit to Canada; failing such notice, he is deemed to be so satisfied. ${ }^{79}$ However, if the Minister is unable to complete his consideration of the
73. Supran. 1, s. 6.
74. Supra n. 2, s. 7(1).
75. Id. ss. 8(1) and (2).
76. See, e.g., ICA, ss. 17(1) and 21(1).
77. See Foreign Investment Review Regulations, 1983, supra n. 11, s. 5(2), (3), (4) and (5).
78. Advice to author by FIRA representative.
79. Supra n. 1, s. 21. 
proposed investment within this forty-five day period, he must send the applicant a notice to that effect and make his decision within a further thirty day period..$^{80}$ Nevertheless, if the Minister is not satisfied within the initial forty-five day priod or such subsequent thirty day period that the investment is likely to be of net benefit to Canada, i.e., if the Minister cannot make a positive decision, he must so notify the applicant and give him thirty days in which to make representations and submit undertakings. ${ }^{81}$ Accordingly, it is only if the Minister concludes during a thirty day extension that he must make a negative decision, that the ultimate decision could be delayed as long as an aggregate of 105 days, i.e., forty-five plus thirty plus thirty days. Beyond that, the review period could only be extended "as may be agreed on by the Applicant and the Minister". ${ }^{82}$ While one cannot overlook the pressure which the Minister could bring to bear on an applicant to agree to such an extension, the fact is that the onus has shifted to the Minister in the ICA.

As with FIRA, all information received by Investment Canada, other than that contained in written undertakings relating to an investment that has been allowed, must be held in confidence by the government. ${ }^{83}$

Except as noted above, the review process itself should not be substantially different from that under FIRA. Of course, this does allow for a good deal of flexibility. Indeed, during 11 years, the administration of the FIR Act varied significantly from time to time depending upon the policy objectives of the day and the personalities of the Cabinet, the Minister and the Commissioner of FIRA. The most obvious contrast has been in the last three years. During the tenure of the Honourable Herb Gray as Minister responsible for the Act from 1980 until the fall of 1982, FIRA became a substantial impediment to foreign investment. Delays and disallowances were relatively high. However, in the federal budget of June 28, 1982, the then Minister of Finance stated that FIRA's procedures "must be timely and efficient. In particular, efforts must be made to avoid red tape and extended delays." Significant administrative reforms were announced two days later by Mr. Gray. In the autumn of 1982 a new Minister and a new FIRA Commissioner were appointed and

80. Id. s. 22(1).

81. Id. s. $23(1)$.

82. Id.

83. Id., s. 36, FIR Act, s. 14(1). An unusual example of the seriousness of this provision is provided by the case of Re Gowling \& Henderson and The Queen (1982) 136 D.L.R. (3d) 292. The applicant firm of solicitors made an unsuccessful application to the Ontario High Court of Justice to quash, on the grounds of solicitor-client privilege, a search warrant issued to The Royal Canadian Mounted Police (RCMP) to search the applicant's premises. The firm acted for an American company which had filed an application with FIRA in connection with a proposed acquisition of a Canadian business. Canadian management of the business made an alternative "application" to FIRA, i.e. attempted to dissuade FIRA from allowing the American proposal. It appeared that the applicant firm of solicitors had obtained knowledge of the details of such alternate Canadian proposal. FIRA believed that such information could only have been obtained from the working files held by one of the two FIRA assessment of ficers. The search warrant was issued to enable the RCMP to obtain evidence for the possible prosecution of the unnamed public servant. The application to quash the search warrant was dismissed on the grounds that the "administration of justice" needs outweigh the "privacy" needs which lay at the basis of solicitor-client privilege. 
by the time of the election of the new Progressive Conservative government in September of 1984, the administration of FIRA had been substantially eased, although its image with the international investment community had not improved. Since then, of course, the government has administered the FIR Act almost as if the ICA had already been enacted. In fact, there has not been a single disallowance!

While the ICA can be expected in the short run to be administered in a similarly benign way, in the hands of a different Minister, with different policy objectives, it could be administered in a way more reminiscent of the pre-June 1982 practice. However, any Minister would have to respect the modified purpose clause and review mechanisms in the ICA.

One likely difference in the administration of the ICA will be an increased access to the ultimate decision-maker. This will be all to the good. A frequent criticism of FIRA was that the foreign investor could not negotiate with the decision-maker, i.e., the federal cabinet. He was often in the position of extending an open offer to a hidden of feree who did not disclose his position; in other words, the foreign investor was "shadow boxing"'. Since the Minister makes the decision under the ICA, he will be more apt to meet with the foreign investor and "strike a deal". Presumably, this responsiveness will be enhanced because the Minister has far fewer applications to contend with than he did under the FIR Act and, furthermore, because he cannot be overruled. Similarly, he will be less reluctant to authorize his agents in Investment Canada to make commitments in the negotiation process. This should have a very salutary effect on the whole review process.

\section{ROLE OF OTHER INTERESTED PARTIES}

Like the FIR Act, the ICA instructs the Minister to take into consideration industrial and economic policy objectives enunciated by the government or legislature of any province likely to be significantly affected by the investment. ${ }^{84}$ FIRA interpreted this to mean the provinces in which the target company or proposed new business, as the case might be, were or would be located. As a matter of course, FIRA sent a copy of the application to the government of each such province or, in the case of the small business procedures, a telexed summary. Hence, the opinion of such provincial government was, and will continue to be, important to the success of an application, because the federal government is reluctant to veto the strongly-held opinion of a provincial government. Depending upon the circumstances, it may be wise for an applicant to communicate independently with the relevant provincial government and, indeed, to send to it directly a copy of the ICA application. Since the provincial governments usually have policies receptive to foreign investment, they are of ten useful allies.

Of course, other branches of the federal government itself may be interested in a particular application. This is obviously the case if a target company or a proposed new business is in an industry which is specifically regulated by the federal government. For example, the Minister of

84. Supran. 1, s. 20(c); supra n. 2, s. 2(2)(e). 
Energy, Mines and Resources participated in a joint press conference with the Minister responsible for the FIR Act to announce the allowance under the FIR Act of the 1984 acquisitions of control of Gulf Canada Limited by Chevron Corporation and of Canadian Reserve Oil \& Gas Ltd. by Texaco Inc. ${ }^{85}$ It was clear that the Department of Energy, Mines and Resources had been involved in the negotiations leading to the allowance.

Furthermore, as with the FIR Act, the ICA instructs the Minister to take into account the effect of the investment on competition. ${ }^{86}$ FIRA routinely advised the Bureau of Competition Policy of each application received and it can be safely assumed that Investment Canada will follow the same policy.

One of the most difficult aspects of the FIRA process was that third parties sometimes intervened and made representations concerning a particular application. Indeed, because of the confidentiality requirements of the FIR Act, such intervenors were able to make such representations privately and confidentially. In such circumstances, the applicant was in the position of not knowing the full case that he had to meet in order to convince FIRA of the merits of his application.

Such intervenors might simply be competitors, or they might be prospective purchasers who wished the application to be disallowed so that

85. E.g., the FIRA press release of February 7, 1985 relating to the Chevron acquisition was as follows:

"The Honourable Sinclair Stevens, Minister responsible for the administration of the Foreign Investment Review Act, today announced the decision of the Governor in Council allowing the acquisition by Chevron Corporation of control of Gulf Canada Limited. The acquisition of control resulted indirectly from Chevron Corporation's successful public tender of fer in the United States for Gulf Corporation in mid-1984.

Mr. Stevens and his colleague, the Honourable Pat Carney, Minister of Energy, Mines and Resources stated that they were particularly pleased with undertakings given by Chevron that it would offer its shareholding in Gulf Canada Limited for sale to Canadian-controlled purchasers until April 30, 1985. Mr. Stevens said that Chevron Corporation had indicated it was prepared to negotiate with any such "responsible and creditworthy Canadiancontrolled" purchaser to sell such shareholding "for a fair and reasonable price". He noted that this would "undoubtedly constitute the largest instance of Canadianization in the history of the Canadian oil and gas industry or, indeed, any Canadian industry".

Miss Carney indicated that Chevron Corporation had agreed that, if no Canadiancontrolled purchaser could be found, then Chevron Corporation would take all reasonable steps to ensure that Canadians had the opportunity to participate in the ownership of Chevron's combined businesses in Canada, including Gulf Canada Limited, to an extent greater by at least twenty percent. This commitment would be met by December 31, 1989.

Miss Carney stressed that Chevron agreed to ensure that Canadian ownership in its Hibernia interests would be maintained or improved. She also indicated that, if no Canadiancontrolled purchaser could be found, Chevron Corporation has undertaken to maintain future exploration and development efforts in Canada at least as great as those planned by Gulf Canada Limited and Chevron's other Canadian companies. This would amount to expenditures in the range of $\$ 800$ million for 1985 .

Mr. Stevens said that it was clear that the Government's new positive attitude toward foreign investment was beginning to pay real dividends for Canada. He said, "My colleague and $l$ are gratified to see that Chevron's indirect acquisition, which resulted from a much larger acquisition abroad, will bring substantial benefits to Canada in terms of Canadian participation in the oil and gas sector and solid commitments to exploration for new energy supplies."

86. Supran. 1, s. 20(d); supra n. 2, s. 2(2)(d). 
they might themselves negotiate to acquire the target company and, in the case of a Canadian, to acquire it at a depreciated market value. In the latter case, FIRA was known to request that an intervenor present his proposal as an alternative purchaser of the target company by submitting his information as if it were a notice filed under the FIR Act. Then FIRA was in a position to make a comparison of the competing bids. While in recent years the applicant was advised of the fact of such intervention and its general nature, neither the details thereof nor the identity of the intervenor was disclosed.

The author has argued elsewhere that this practice by FIRA was ultra vires and could be challenged on general principles of administrative law. ${ }^{87}$ The ICA would appear, if anything, to be somewhat more restrictive in what it authorizes the Minister to consider. Accordingly, it is submitted that the consideration of intervenor bids is not authorized under the ICA.

\section{NOTIFICATION}

Part III of the ICA provides that an investment by a non-Canadian to establish a new Canadian business, and an investment by a non-Canadian to acquire control of a Canadian business, unless it is reviewable pursuant to s. 14 , is subject to notification. ${ }^{88}$ The exemptions in Part II of the ICA also apply to such notification requirements.

Acquisitions of control have been previously discussed. However, an investment to establish a "new Canadian business" is slightly different from the concept in the FIR Act of a proposal to establish a "new business in Canada" which, of course, was reviewable. The FIR Act provided that every non-eligible person, and every group of persons any member of which was a non-eligible person, must file an application with FIRA if: 89

(a) immediately before the time when the new business was proposed to be established no other business was carried on in Canada by that person or group of persons, or

(b) each of the businesses carried on in Canada by that person or group of persons immediately before was a business to which the new business would, if it was established, be "unrelated".

Hence, the screening process extended to new direct investment by foreign investors who had not before carried on business in Canada and also to diversification by existing foreign-controlled firms into "unrelated" lines of business. These provisions were restricted to new direct investment in businesses which were to have an actual physical presence in Canada. This followed from the fact that the FIR Act provided that a business was established in Canada only if there was an establishment in Canada to which one or more employees reported for work in connection with the business; it further provided that the time at which a business was established was the time at which the first of such employees reported for work at such establishment. ${ }^{90}$

87. Supran. 67.

88. Supran. 1, s. 11.

89. Supran. 2, s. 8(1) and (2).

90. Id. s. 3(4). 
The provisions of the ICA are similar but less elaborate from a drafting standpoint. They also reflect the desire to be able to review new businesses in the cultural heritage or national identity sectors even if related to another business being carried on in Canada by the foreign investor. The ICA's definition of "new Canadian business" is:"1

$\ldots$ a business that is not already being carried on in Canada by the non-Canadian and that, at the time of its establishment,

(a) is unrelated to any other business being carried on in Canada by that non-Canadian, or

(b) is related to another business being carried on in Canada by that non-Canadian but falls within a prescribed specific type of business activity that, in the opinion of the Governor in Council, is related to Canada's cultural heritage or national identity.

It will be seen that the first part of this definition neatly summarizes the two parts to the definition of new business in the FIR Act.

The time at which a new Canadian business is established is the time at which it becomes a Canadian business. ${ }^{92}$ A "Canadian business" is defined to mean: ${ }^{93}$

... a business carried on in Canada that has,

(a) a place of business in Canada,

(b) an individual or individuals in Canada who are employed or self-employed in connection with the business, and

(c) assets in Canada used in carrying on the business.

Hence, the definitions of establishing a new business under the ICA are substantially identical to those in the FIR Act except that, to the extent it requires notification, and possible review, of related new businesses, the ICA is actually more restrictive than the FIR Act. Basically, these provisions are restricted to new direct investment in businesses which are to have an actual physical presence in Canada.

Where an investment is subject to notification, the non-Canadian must, within thirty days of making the investment, give notice in the prescribed form. ${ }^{94}$ It is anticipated that this information will be of a most cursory nature. Unless an Order in Council is subsequently issued requiring review under $\mathrm{s} .15$ because of the cultural heritage or national identity significance of the investment, filing of the notice will be the end of the matter.

\section{APPEALS AND OPINIONS}

As with the FIR Act, a decision by the government under the ICA is not appealable. This reflects Parliament's continuing philosophy that the decision on whether to allow a proposed foreign investment should be made on grounds of policy rather than law. Nevertheless, an application which has been disallowed can always be re-submitted. Presumably, this will not be done unless there are significant new factors or undertakings to be offered for consideration.

The FIR Act provided that the Minister must provide binding opinions on whether a person was a non-eligible person or a particular business

\footnotetext{
91. Supra n. 1, s. 3.

92. Id. s. 32(1).

93. Id. s. 3.

94. Id. s. 12.
} 
was related to another particular business. ${ }^{95}$ However, the Minister's opinion could not be obtained on any of the other equally critical questions under the Act although, over time, the practice grew up whereby FIRA gave "no action letters"' and, ultimately, "Agency opinions"'. ${ }^{96}$ The problem was that these Agency opinions were stated to be not binding on the Minister. This situation has been rectified by s. 37 of the ICA, under which the Minister or Investment Canada must give binding opinions on some matters and may give opinions on other matters.

As with the FIR Act, under the ICA the Minister may issue and publish guidelines with respect to the application or administration of the legislation. ${ }^{97}$ However, the ICA contains the additional authority to issue interpretation notes, providing a legislative basis for these which was lacking in the FIR Act.

\section{ENFORCEMENT}

The enforcement provisions of the ICA reflect a different attitude than ihose of the FIR Act. Under the latter, failure to give notice of a proposed investment led, in the first instance, to a summary conviction of fence punishable by a fine not exceeding 5,000 dollars. ${ }^{98}$ Refusal to file a notice after having been served with a demand to do so by the Minister under s-s. 8(3) of the FIR Act could give rise to a fine not exceeding 10,000 dollars or imprisonment for a term not exceeding six months or to both. ${ }^{99}$

By contrast, where a non-Canadian fails to file a required notice or application, or implements an investment contrary to the ICA, the Minister may send him a demand to cease the contravention, to remedy the default and so forth. Where the non-Canadian fails to comply with such demand, the Minister may apply to a Superior Court for an order providing a civil remedy. ${ }^{100}$ Such remedy could include a penalty not exceeding 10,000 dollars for each day of contravention of the ICA. ${ }^{101}$ Nevertheless, it is a civil penalty, not a fine for an offence.

The ultimate remedy, of course, under the FIR Act was an order of a Superior Court rendering an investment "nugatory". ${ }^{102}$ While views of the meaning of this word varied, many thought it could include rendering the investment void, with potentially horrendous consequences. The ICA drops this Draconian measure and contemplates, instead, an order for divestiture. ${ }^{103}$

\section{TRANSITIONAL PROVISIONS}

The FIR Act is repealed by the ICA. ${ }^{104}$ However, there are provisions to govern the transition from the old to the new system. One of the most

95. Supran. 2, s. 4(1).

96. See FIRA's Information Circular Concerning Agency Opinions dated August 1982.

97. Supra n. 1, s. 38; supran. 2, s. 4(2).

98. Supra n. 2, s. 24(1).

99. Id. s. 24(2).

100. Supra n. 1, s. $40(1)$.

101. Id. s. 40(2)(d).

102. Supra n. 2, s. 20(1).

103. Supran. 1, s. 40(2)(f).

104. Id. s. 46. 
important is that undertakings given in connection with, and all terms and conditions of, an investment allowed under the FIR Act are enforceable even where the investment would not be reviewable under the ICA. ${ }^{105}$ This has generated some adverse criticism by foreign investors who feel they are being put at a competitive disadvantage. However, it is believed the government felt that it could not be seen to be giving up all the "advantages" previously negotiated on behalf of Canada. In any event, it is understood that the government is reviewing all outstanding undertakings with a view to sifting out those which will continue to be monitored for compliance.

Legal proceedings pending under the FIR Act may be continued and legal proceedings may be taken under the ICA in respect of an investment which is the subject of any deemed allowance or order under the FIR Act. ${ }^{106}$

Investors who have filed notices under the FIR Act which have not been disposed of on the coming into force of the ICA will not be required to re-file under the ICA and will be deemed to have filed a completed application, or notification, the day the ICA comes into force. ${ }^{107}$

Any investment for which a notice should have, but was not, filed under the FIR Act will be deemed to be implemented on the day the ICA comes into force. ${ }^{108} \mathrm{Hence}$, if it is reviewable under the ICA, an application thereunder must be filed. However, if it is not reviewable under the ICA, only a notification need be filed even though it was reviewable under the FIR Act.

Where a person has a binding opinion under the FIR Act that he is not a non-eligible person, he is deemed to be a Canadian under the ICA for the lesser of two years from the date of its coming into force and so long as the material facts on which such opinion was based remain substantially unchanged. ${ }^{109}$

It appears that under the Interpretation Act (Canada), the repeal of the FIR Act will not eliminate its of fence provisions and that, accordingly, any person who knowingly failed to file thereunder may be subject to its of fence provisions even after its repeal. ${ }^{110}$

The transitional provisions also provide that information privileged under the FIR Act will be accorded the same privilege as information under s. 36 of the ICA. ${ }^{111}$

The ICA specifically amends s. 35 of the Canadian Ownership and Control Determination Act (Canada) and s. 2 of the Northern Pipeline Act (Canada) to provide that any reference therein to the FIR Act shall be construed as a reference to the FIR Act as it read immediately before the coming into force of the ICA. ${ }^{112}$

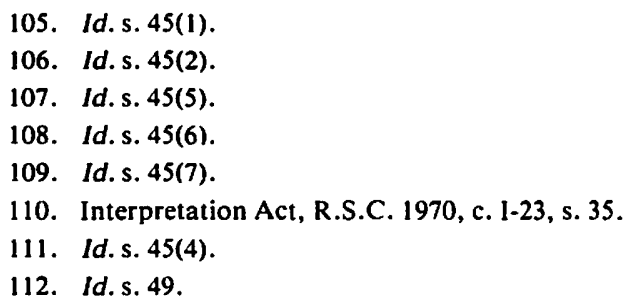

